International Journal of Social Sciences and Humanities
Available online at www.sciencescholar.us
Vol. 6 No. 1, April 2022, pages: $75-84$
e-ISSN: 2550-7001, p-ISSN: 2550-701X
https://doi.org/10.53730/ijssh.v6n1.4738

\title{
Relationship of Information Sources and Knowledge with Completeness of Primigravida's Tetanus Toxoid Immunization
}

\author{
Andi Wilda Arianggara ${ }^{a}$, Ernawati ${ }^{b}$, Titi Purwitasari Handayani c, Febriana Sari ${ }^{d}$, Lia Fitria ${ }^{\text {e }}$
}

Manuscript submitted: 27 Dec 2021, Manuscript revised: 09 Jan 2022, Accepted for publication: 18 Feb 2022

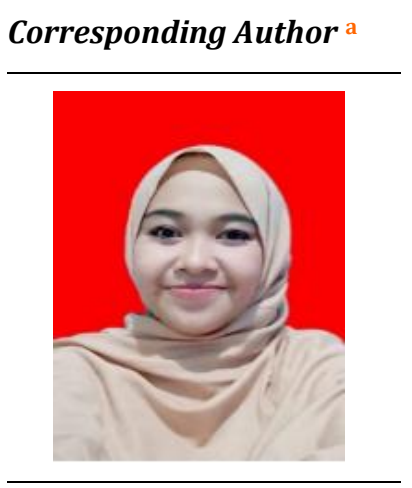

Keywords

immunization; information sources; knowledge completeness; primigravida; tetanus toxoid;

\begin{abstract}
TT immunization coverage in Kassi-Kassi Health Center is still low. The achievement of tetanus toxoid immunization coverage can be influenced by several factors, including sources of information and knowledge about TT immunization. The purpose of this study is to find out the relationship between sources of information and knowledge with the completeness of Tetanus Toxoid Immunization Mrs. Primigravida at Kassi-Kassi Health Center Makassar city. This type of research is an Analytical Survey with a cross-sectional design. The sample in this study was all primigravida mothers with the gestational age of more than 32 weeks and primigravid mothers who had been immunized TT1 and TT2 in Puskesmas Kassi-Kassi numbered 35 people. Data analysis using the Chi-Square test with a $95 \%$ confidence level $(\alpha=0.05)$. The results showed that there is a meaningful relationship between the source of information $(\mathrm{p}=$ $0.020)$ and knowledge $(p=0,000)$ with the Completeness of Immunization TT Ibu Pimigavida in Puskesmas Kassi-Kassi Makassar City. Puskesmas is expected to improve promotive and preventive functions to be able to increase public knowledge about TT immunization so as to increase TT immunization coverage.
\end{abstract}

International Journal of Social Sciences and Humanities (C) 2022.

This is an open access article under the CC BY-NC-ND license (https://creativecommons.org/licenses/by-nc-nd/4.0/).

\footnotetext{
${ }^{a}$ Mitra Bunda Institute of Health, Batam, Riau Islands, Indonesia

${ }^{b}$ Institute of Health Sience Karsa Husada Garut, West Java, Indonesia

${ }^{c}$ Institute of Health Sience Karsa Husada Garut, West Java, Indonesia

d Institute of Health Sience Mitra Husada Medan, North Sumatra, Indonesia

e Univercity of Ibrahimy, Situbondo, East Java, Indonesia
} 


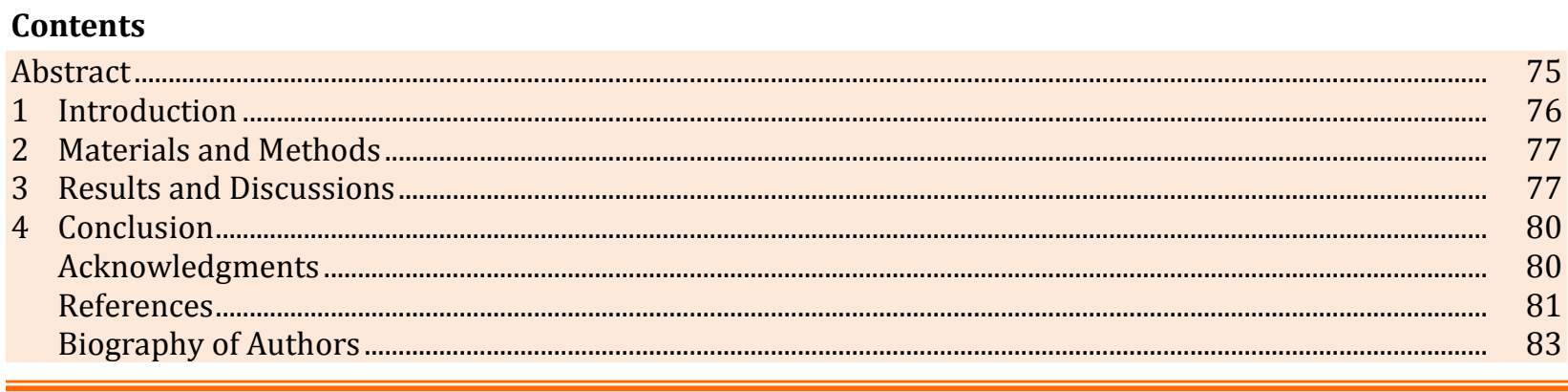

\section{Introduction}

Pregnancy is a natural process, although it is not denied in some cases there may be complications early on due to certain conditions or occur later in life resulting in high morbidity and mortality in the mother (Kuswanti, 2014). Maternal morbidity and mortality rates are still serious health problems in developing countries. According to a 2014 Worid Health Organization (WHO) report, the world's maternal mortality rate (AKI) is 289,000. Some countries that have a fairly high AKI such as Sub-Saharan Africa 179,000 people, South Asia 69,000 people, and Southeast Asia 16,000 people (WHO, 2014).

Based on data from the Indonesian Health Demographic Survey (SDKI) 2012, AKI in Indonesia is still high compared to other ASEAN countries. AKI in Indonesia increased from 228/10,000 births in 2007 to 359/100,000 Live Births (KH) in 2012. In the same year, the Ministry of Health launched the Expanding Maternal and Neonatal Survival (EMAS) program in an effort to reduce maternal and neonatal mortality by $25 \%$. But this effort was not completely successful, AKI in Indonesia in 2015 is still far from the target set at 305 maternal deaths per 10,000 KH, although it has decreased but still did not reach the predetermined target (Kemenkes, 2014).

The cause of the high maternal mortality rate in Indonesia is caused by several factors, namely the cause of direct death and the cause of indirect death. The five biggest causes of maternal mortality are bleeding, hypertension in pregnancy, abortus, long partus/ jammed and infection (Kemenkes, 2016). Tetanus infection is one of the causes of maternal death caused by clostridium tetani bacteria as a result of an unsafe /sterile delivery process or derived from wounds obtained by pregnant women before giving birth. As a priority effort of the Ministry of Health as outlined in Health Law No. 36 of 2009, to prevent tetanus infection which is one of the risk factors for maternal death and infant death, tetanus toxoid immunization program (TT) is implemented for Women of Childbearing Age (WUS) and pregnant women (Pusdiknakes, 2016).

According to Astuti et al. (2017), in the journal Rahmawati Year 2015 Tetanus Toxoid Immunization is an immunization given to pregnant women to prevent the occurrence of tetanus noenatorum. According to Fausiah (2012), immunization tetanus toxoid for pregnant women who have received tetanus toxoid 2 times in the previous pregnancy or at the time of the bride and groom, then immunization is enough to be given 1 time only with a dose of $0.5 \mathrm{cc}$ on the upper arm. If pregnant women have not been immunized or in doubt, it is necessary to be immunized tetanus toxoid since the first visit as many as 2 times (TT1 and TT2) with a minimum interval schedule of 1 month (Rahmawati, 2015).

Based on the results of research by the Directorate General of Disease Prevention and Control, tetanus toxoid immunization coverage in pregnant women in Indonesia amounted to $1,616,620$ (30.43\%) for TT1 immunization coverage and 1,271,889 (23.94\%) for TT2 coverage of 5,312,100 pregnant women in all provinces in Indonesia. TT immunization coverage in pregnant women in South Sulawesi in 2016, amounted to $72,327(38.46 \%)$ for TT1 immunization coverage and $65,555(34.86 \%)$ for TT2 immunization coverage from 188,046 pregnant women. The data showed low TT immunization coverage in pregnant women, and immunization coverage from TT1 to TT2 showed a significant decrease of 6,772 (3.6\%) (Kemenkes, 2017).

TT immunization coverage in pregnant women for Makassar City in 2015, amounted to 19,240 (69.01\%) for TT1 coverage and 5,571 (19.98\%) for TT2 coverage of 27,880 pregnant women. And TT immunization coverage for Rappocini Subdistrict from 3 Health Centers, namely, Puskesmas Kassi-Kassi TT1 coverage of $768(46.69 \%)$ and for TT2 immunization coverage of $56(3.40 \%)$ of 1645 pregnant women. For Mangasa Health Center, TT1 immunization coverage is 949 (91.96\%) and for TT2 is 87 (8.43\%), while for Puskesmas 
Minasa Upa TT1 immunization coverage is 243 (42.7\%) and TT2 coverage is 110 (19.37\%). From the data above it was obtained that from the three Health Centers, Puskesmas Kassi-Kassi is a Health Center that has a very significant decrease in TT1 to TT2 immunization coverage of 712 (43.29\%) (Dinkes, 2016).

Based on the results of preliminary studies conducted at kassi-kassi health center obtained data for 2017 from 1869 pregnant women, TT1 immunization coverage of 1516 (81\%), and for TT2 coverage of 757 (41\%). From the data above it can be concluded that there is a negating decrease in the number of TT1 to TT2 coverage of $759(40 \%)$ and based on the results of interviews conducted by researchers from 6 pregnant women obtained that, pregnant women say no TT immunization because according to the mother and child are healthy, so there is no need to do TT immunization, pregnant women say they do not know the dangers if they do not immunize TT, Pregnant women say they do not know about the importance of TT immunization, pregnant women say they do not know the schedule of TT immunization. This maternal ignorance is due to a lack of information and knowledge about tetanus toxoid immunization (Pandey et al., 2010; Love et al., 2013). According to Green, L in Hikmawati \& Rusmiyati (2011), there are several predisposing factors that determine the behavior to immunize TT in pregnant women such as knowledge, attitude, and trust. Because of the extent of predisposing factors and because of the researcher's determination in researching the entire factor, the researcher focuses his research on knowledge factors and sources of information. The purpose of this study is to find out the relationship of information and knowledge sources with the completeness of tetanus toxoid immunization of Ibu primigravida in Puskesmas Kassi-Kassi Makassar City (Barry \& Johnston, 1997; Thompson Jr, 2000).

\section{Materials and Methods}

The type of research used is an analytical survey with a cross sectional approach which is a type of research that aims to provide an overview of reality or objective data (Notoatmodjo, 2010). While the cross sectional approach is a study conducted with observation (data collection) at once in a certain time (point time approach) and each study subject was only made one observation (data) during the study. This research was conducted at Kassi-Kassi Health Center located on Jalan Tamalate 1 Makassar, Rappocini, Makassar City. The population in this study were all primigravida mothers in kassi-kassi health center. Sampling techniques in this study were conducted randomly (randomly) namely with Probabillity sampling and researchers using sampling methods with the Simple Random Sampling technique that is by way of population members set according to the criteria to then randomize using Excel programs on the computer. The tools used in the study were questionnaires taken from previous studies and had been modified by the researchers themselves. Before being used as a research instrument, questionnaires have been tested with tests of validity and reliability. After the data is collected then data analysis is done using quantitative statistical techniques using univariate analysis and bivariate analysis. Univariate analysis produces only the frequency distribution and percentage of each variable. While bivariate analysis uses one of the non-parametric statistical tests, namely with the Chi-square test with the alternative Excat Fisher Test with the help of computer programs.

\section{Results and Discussions}

Table 1

Respondents' characteristics

\begin{tabular}{lccc}
\hline & Characteristic & $\begin{array}{c}\text { Frequency } \\
(\mathrm{n})\end{array}$ & $\begin{array}{c}\text { Percent } \\
(\%)\end{array}$ \\
\hline \multirow{2}{*}{ Age } & 15-19 years old & 10 & 28,6 \\
& 20-35 years & 25 & 71,4 \\
\multirow{2}{*}{ Education } & Sum & 35 & 100 \\
& & 2 & 5,7 \\
& Primary School & 6 & 17,1 \\
\hline
\end{tabular}

Arianggara, A. W., Ernawati, E., Handayani, T. P., Sari, F., \& Fitria, L. (2022). Relationship of information sources and knowledge with completeness of primigravida's tetanus toxoid immunization. International Journal of Social Sciences and Humanities, 6(1), 75-84. https://doi.org/10.53730/ijssh.v6n1.4738 


\begin{tabular}{clcc}
\hline & Senior High School & 18 & 51,4 \\
& College & 9 & 25,7 \\
& Sum & 35 & 100 \\
Profession & Private Employees & 3 & 8,6 \\
& Housewife & 32 & 91,4 \\
& Sum & 35 & 100 \\
\hline
\end{tabular}

Source: Primary Data, 2018

From the table above it can be concluded that for the age category, the most respondents are in the age range of 20-35 years as many as $25(71.4 \%)$ respondents. As for the education category, the respondents were mostly at the senior high school education level as much as 18 (51.4\%). And for the job category, respondents with housewife jobs were the most popular, at 32 (91.4\%) respondents (Miller Jr et al., 1999; Wilson et al., 2020).

Table 2

Relationship of information source with completeness of tetanus toxoid immunization Mrs. Primigravid

\begin{tabular}{lcll}
\hline \multirow{2}{*}{ Source of Information } & \multicolumn{2}{c}{ TT Immunization } & \multirow{2}{*}{ Completeness } \\
& Complete & Incomplete & \\
\hline Immediately & $19(76 \%)$ & $6(24 \%)$ & $25(100 \%)$ \\
Indirect & $3(30 \%)$ & $7(70 \%)$ & $10(100 \%)$ \\
Sum & $22(62,9 \%)$ & $13(37,1 \%)$ & $35(100 \%)$ \\
\hline
\end{tabular}

Source: Primary Data, 2018

Table 2, shows that primigravida mothers who get the source of information directly, namely as many as 25 respondents. Of the 25 respondents, there were 19 respondents $(76.0 \%)$ who had complete TT immunization status and 6 respondents $(24.0 \%)$ who had incomplete TT immunization status, while primigravid mothers who were indirectly informed as many as 10 respondents. Of the 10 respondents, there were 3 respondents (30.0\%) who had complete TT immunization status and 7 respondents $(37.1 \%)$ who had incomplete TT immunization status. After the Chi-Square analysis using an alternative Excat Fisher Test with a confidence level of $95 \%$ obtained $a$ p-value of 0.020 which means less than $\alpha$-value (0.05). Thus it can be stated that H0 is rejected (Brosens et al., 2015; Kızılırmak \& Başer, 2016).

Furthermore, to assess the strength of the relationship between variables, the association test (phi) and obtained the value of phi $(\mu)=0.430$ with a percentage of $43 \%$, so it can be interpreted that the strength of the relationship between the source of information with the completeness of TT immunization is moderate.

Table 3

Knowledge relationship with completeness of tetanus toxoid immunization mother primigravid

\begin{tabular}{llll}
\hline \multirow{2}{*}{ Knowledge } & \multicolumn{2}{c}{ TT Immunization } & Completeness \\
& Complete & Incomplete & Sum \\
\hline Enough & $21(84 \%)$ & $4(16 \%)$ & $25(100 \%)$ \\
Less & $1(10 \%)$ & $9(90 \%)$ & $10(100 \%)$ \\
Sum & $22(62,9 \%)$ & $13(37,1 \%)$ & $35(100 \%)$ \\
\hline
\end{tabular}

Source: Primary Data, 2018

Table 3 showed that Primigravida had enough knowledge as many as 25 respondents. Of the 25 respondents, there were 21 respondents (84.0\%) who had complete TT immunization status and 4 respondents (16.0\%) who had incomplete TT immunization status. While primigravida mothers who have less knowledge are as many as 10 respondents. Of the 10 respondents, there was 1 respondent $(10.0 \%)$ who had complete TT 
immunization status and 9 respondents (90.0\%) who had incomplete TT immunization status (Alonso et al., 1994; Raghuvanshi et al., 2002).

After the Chi-Square analysis using an alternative Excat Fisher Test with a confidence level of 95\% obtained a p-value value of 0.00 which means less than $\alpha$-value $(0.05)$. Thus it can be stated that $\mathrm{H} 0$ is rejected. To find out the strength of the relationship between these variables, an association test (phi) is performed. And obtained the value phi $(\mu)=0.692$ with a percentage of $69 \%$, so it can be interpreted that the strength of the relationship between knowledge and the completeness of TT immunization is strong (Herman et al., 2022; Asriyati et al., 2021).

\section{Relationship of information source with completeness of immunization tt Mrs. Primigravida}

The results of the above study are in line with the results of Asiah research (2012) entitled relationship of education, information from health workers, and family support with the implementation of TT immunization in pregnant women at Sigli General Hospital shows that there is an informational relationship from health workers with the implementation of TT immunization in pregnant women ( $\mathrm{p}$ value $=0.001$ ). The source of information is a very necessary thing so that information can be conveyed and can be received by the recipient of the information. Direct sources of information will allow a great influence on the formation of one's opinions and beliefs, as it is possible for the recipient of the information to have a direct dialogue with the information giver, either to ask if the information provided does not understand or convey his opinion so that more information can be obtained by the recipient of the information.

Various information obtained by pregnant women about the importance of TT immunization, can make the interest of pregnant women to do TT immunization will increase but if pregnant women do not get information about TT immunization then pregnant women do not understand so they do not do TT immunization as expected (Asiah, 2012). Based on the discussion above, there can be a meaningful relationship between the source of information with the completeness of Tetanus Toxoid immunization in primigravida mothers in The Kassi-Kassi Health Center of Makassar City, marked by $p$-value $=0.02$ and the strength of the relationship between the two variables is medium with a percentage of $43 \%$.

\section{Knowledge relationship with completeness of immunization TT Mrs. Primigravida}

The results of the above study are in line with the theory that pregnant women's knowledge about TT immunization is needed because with high knowledge about TT immunization it is expected that they will want to do complete TT immunization. Immunization is very important given to pregnant women because with complete immunization, pregnant women have strong immunity and are not susceptible to diseases, especially tetanus (Kasmawati, 2013). Based on the results of research conducted (Safitri et al., 2016). The relationship of knowledge level of pregnant women with participation in immunization tetanus toxoids in Puskesmas Gongang Sragen regency shows the relationship of knowledge of pregnant women with participation in immunization tetanus toxoid ( $\mathrm{p}$ value $=0.001$ ).

The knowledge possessed by primigravida mothers is very influential to carry out TT immunization. The higher and broader the knowledge that primigravid mothers have about TT immunization be it benefits, immunization time, and how to immunize TT, it will further increase the desire of pregnant women to do TT immunization. Vice versa, the lower the knowledge possessed by pregnant women about TT immunization, the less interest pregnant women to do TT immunization. Knowledge about TT immunization can be obtained by pregnant women both directly and from indirectly, which aims to improve the attitude and behavior of pregnant women in carrying out TT immunization (Kasmawati, 2013). Based on the discussion above, there can be a meaningful relationship between knowledge and the completeness of Tetanus Toxoid immunization in primigravida mothers in The Kassi-Kassi Health Center of Makassar City, marked by $p$-value $=0.00$ and the strength of the relationship between the two variables is strong with a percentage of $69 \%$.

Arianggara, A. W., Ernawati, E., Handayani, T. P., Sari, F., \& Fitria, L. (2022). Relationship of information sources and knowledge with completeness of primigravida's tetanus toxoid immunization. International Journal of Social Sciences and Humanities, 6(1), 75-84. https://doi.org/10.53730/ijssh.v6n1.4738 


\section{Conclusion}

Based on the results of the research that has been obtained, it can be concluded that:

a) Information Sources directly contributes to the completeness of Tetanus Toxoid immunization in primigravida mothers in Kassi-Kassi Health Center Makassar city.

b) Knowledge is one of the determining factors for the completeness of Tetanus Toxoid immunization in primigravida mothers in Kassi-Kassi Health Center Makassar city.

Acknowledgments

We are grateful to two anonymous reviewers for their valuable comments on the earlier version of this paper. 


\section{References}

Alonso, M. J., Gupta, R. K., Min, C., Siber, G. R., \& Langer, R. (1994). Biodegradable microspheres as controlledrelease tetanus toxoid delivery systems. Vaccine, 12(4), 299-306. https://doi.org/10.1016/0264410X(94)90092-2

Asiah. (2012). Educational Relations, Information From Health Workers and Family Support With The Implementation of TT Immunization in Pregnant Women, Sigli.

Asriyati, P. E., Swarjana, I. K., Sastriani, N. L. A., \& Krisnandari, A. A. I. W. (2021). The effect of electronic discharge planning with SBAR approach to optimize the implementation of patient discharge. International Journal of Health \& Medical Sciences, 4(3), 280-287. https://doi.org/10.31295/ijhms.v4n3.1750

Astuti, S., Susanti, A. I., Nurparidah, R., \& Mandiri, A. (2017). Asuhan ibu dalam masa kehamilan. Jakarta: EGC.

Barry, M. A., \& Johnston, S. A. (1997). Biological features of genetic immunization. Vaccine, 15(8), 788-791. https://doi.org/10.1016/S0264-410X(96)00265-4

Brosens, I., Benagiano, G., \& Brosens, J. J. (2015). The potential perinatal origin of placentation disorders in the young primigravida.American journal of obstetrics and gynecology,212(5), 580-585. https://doi.org/10.1016/j.ajog.2015.01.013

Dinkes, M. (2016). Profil Kesehatan Kota Makassar 2015.

Dinkes, M. (2016). Profil Kesehatan Kota Makassar 2015.

Dinkes. (2016). Makassar City Health Profile 2015. Retrieved fro dinkeskotamakassar.com.

Fauziah, S. (2012). Keperawatan Maternitas Kehamilan-Vol. 1. Prenada Media.

Herman, H., Ardani, I. G. A. I., Aryani, L. N. A., Windiani, I. G. A. T., Adnyana, I. G. N. S., \& Setiawati, Y. (2022). Signs and symptoms of depression in children and adolescents with type 1 diabetes mellitus: A case report. International Journal of Health \& Medical Sciences, 5(1), 150-153. https://doi.org/10.21744/ijhms.v5n1.1861

Hikmawati, E., \& Rusmiyati, C. (2011). Kebutuhan pelayanan sosial penyandang cacat. Sosio Informa, 16(1).

Kasmawati, K. (2013). Analisis keefektifan pembelajaran berbasis kurikulum 2013 di Sekolah Dasar. Journal of Educational Science and Technology (EST), 3(1), 33-42.

Kemenkes, R. (2014). Pusat Data dan Informasi Ibu.

Kemenkes, R. (2014). Pusat Data dan Informasi Ibu.

Kemenkes, R. (2016). Profil Kesehatan Indonesia 2015. Kemenkes RI, Jakarta.

Kemenkes, R. (2016). Profil Kesehatan Indonesia 2015. Kemenkes RI, Jakarta.

Kemenkes, R. (2017). Profil Kesehatan Indonesia 2016. Kemenkes RI, Jakarta.

Kemenkes, R. (2017). Profil Kesehatan Indonesia 2016. Kemenkes RI, Jakarta.

Kizılırmak, A., \& Bașer, M. (2016). The effect of education given to primigravida women on fear of childbirth. Applied nursing research, 29, 19-24. https://doi.org/10.1016/j.apnr.2015.04.002

Kuswanti, I. (2014). Maternity Care. PT. Student Library., Yogyakarta.

Love, B., Himelboim, I., Holton, A., \& Stewart, K. (2013). Twitter as a source of vaccination information: content drivers and what they are saying. American journal of infection control,41(6), 568-570. https://doi.org/10.1016/j.ajic.2012.10.016

Miller Jr, D. W., Frawley, S. J., \& Miller, P. L. (1999). Using semantic constraints to help verify the completeness of a computer-based clinical guideline for childhood immunization. Computer methods and programs in biomedicine, 58(3), 267-280. https://doi.org/10.1016/S0169-2607(98)00090-X

Notoatmodjo, S. (2010). Promosi kesehatan.

Pandey, A., Patni, N., Singh, M., Sood, A., \& Singh, G. (2010). YouTube as a source of information on the H1N1 influenza pandemic. American journal of preventive medicine, 38(3), e1-e3. https://doi.org/10.1016/j.amepre.2009.11.007

Pusdiknakes. (2016). Buku Ajar Imunisasi. Kemenkes RI, Jakarta.

Raghuvanshi, R. S., Katare, Y. K., Lalwani, K., Ali, M. M., Singh, O., \& Panda, A. K. (2002). Improved immune response from biodegradable polymer particles entrapping tetanus toxoid by use of different immunization protocol and adjuvants. International journal of pharmaceutics, 245(1-2), 109-121. https://doi.org/10.1016/S0378-5173(02)00342-3

Rahmawati, F. L. (2015). Tingkat Pengetahuan Ibu Hamil tentang Imunisasi Tetanus Toksoid I.

Arianggara, A. W., Ernawati, E., Handayani, T. P., Sari, F., \& Fitria, L. (2022). Relationship of information sources and knowledge with completeness of primigravida's tetanus toxoid immunization. International Journal of Social Sciences and Humanities, 6(1), 75-84. https://doi.org/10.53730/ijssh.v6n1.4738 
Safitri, R., Hasan, N., \& Diani, R. (2016). Aspek Hukum Prosedur Administrasi Perkara Di Pengadilan Hubungan Industrial (PHI) Pada Pengadilan Negeri Palembang (Doctoral dissertation, Universitas Tamansiswa Palembang).

Thompson Jr, D. L. (2000). Immunization against GnRH in male species (comparative aspects). Animal Reproduction Science, 60, 459-469. https://doi.org/10.1016/S0378-4320(00)00116-0

WHO. (2014). Maternal Mortality. World Health Organization.

Wilson, S. E., Wilton, A. S., Young, J., Candido, E., Bunko, A., Buchan, S. A., ... \& Tu, K. (2020). Assessing the completeness of infant and childhood immunizations within a provincial registry populated by parental reporting: a study using linked databases in Ontario, Canada. Vaccine, 38(33), 5223-5230. https://doi.org/10.1016/j.vaccine.2020.06.003 


\section{Biography of Authors}

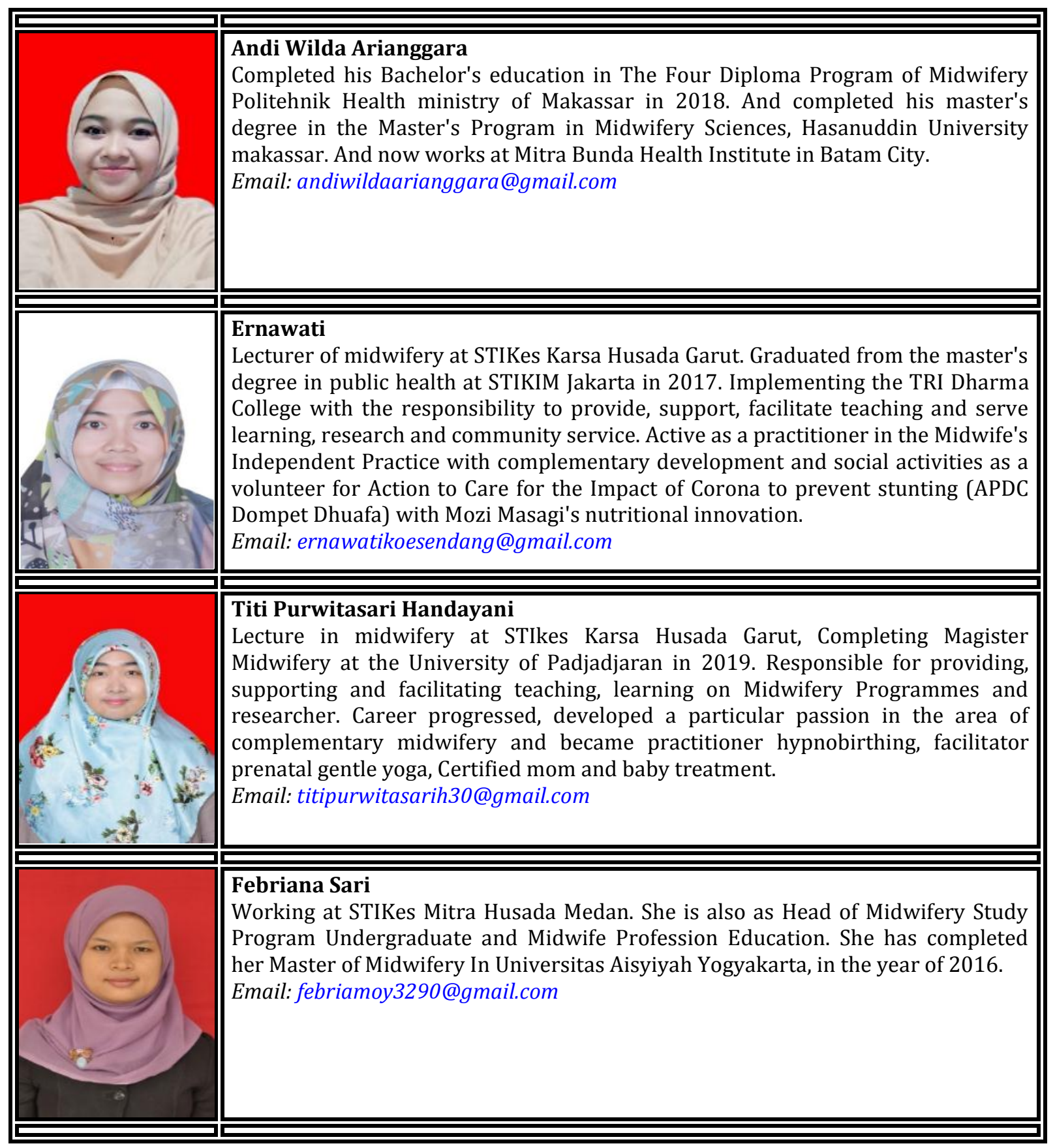

Arianggara, A. W., Ernawati, E., Handayani, T. P., Sari, F., \& Fitria, L. (2022). Relationship of information sources and knowledge with completeness of primigravida's tetanus toxoid immunization. International Journal of Social Sciences and Humanities, 6(1), 75-84. https://doi.org/10.53730/ijssh.v6n1.4738 


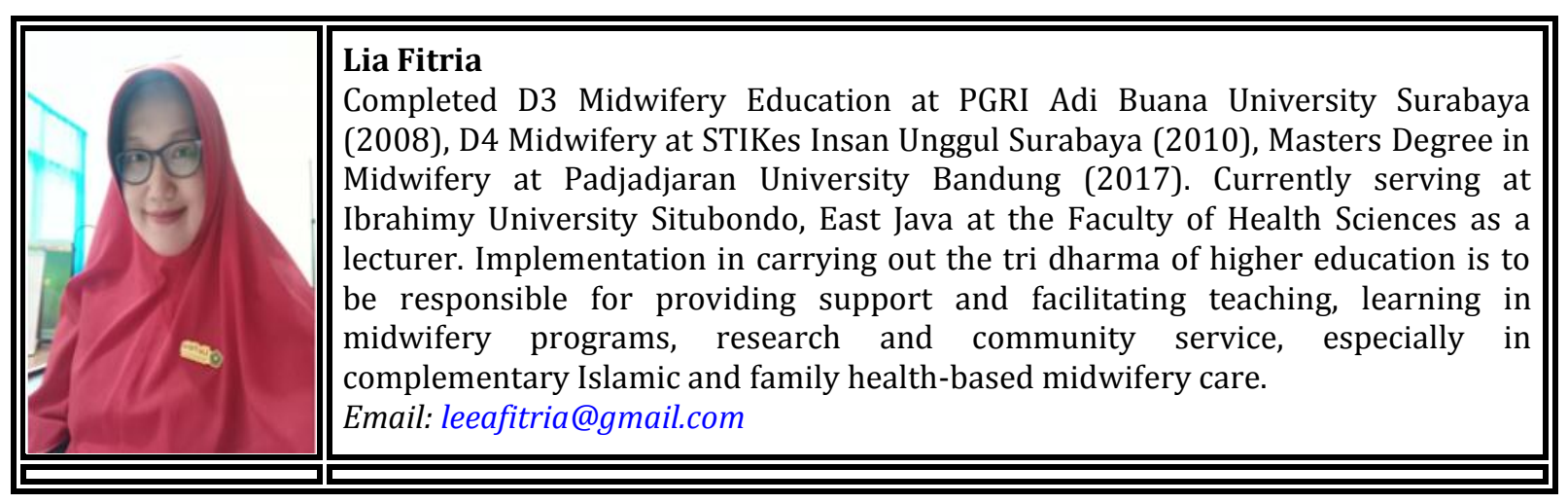

